\title{
Identification and Properties of a Carlavirus Causing Chlorotic Mottle of Florists' Hydrangea (H. macrophylla) in the United States
}

Jose Ernesto Machado Caballero, Ben E. Lockhart, and Shauna L. Mason, Department of Plant Pathology, University of Minnesota, St. Paul, MN 55108; and Margery Daughtrey, Department of Plant Pathology and PlantMicrobe Biology, Cornell University, Riverhead, NY 11901

\begin{abstract}
Machado Caballero, J. E., Lockhart, B. E., Mason, S. L., and Daughtrey, M. 2009. Identification and properties of a carlavirus causing chlorotic mottle of florists' hydrangea (H. macrophylla) in the United States. Plant Dis. 93:891-895.

A previously uncharacterized virus with flexuous filamentous particles $660 \mathrm{~nm}$ in length was identified in the United States in florists' hydrangea (Hydrangea macrophylla), in which it caused chlorotic mottling, leaf deformation, and discoloration. The virus, tentatively named Hydrangea chlorotic mottle virus (HdCMV), was transmitted readily by mechanical inoculation and by Myzus persicae, but infected only $H$. macrophylla. The amino acid sequence of a 1.7-kb amplicon comprising the $3^{\prime}$ terminus of the HdCMV genome contained one partial and three complete putative open reading frames (ORFs) most similar in size, arrangement, and sequence to the homologous regions of the genomes of known carlaviruses. Based on virion morphology, genome properties, and current criteria for species demarcation, it was concluded that HdCMV represented a new species in the genus Carlavirus. Hydrangea ringspot virus (HdRSV, genus Potexvirus) occurred in mixed infections with HdCMV, but the two viruses could be distinguished readily by serological tests.
\end{abstract}

Florists' hydrangea, Hydrangea macrophylla (Saxifragaceae), is a popular summer-flowering shrub prized for its large, brightly colored inflorescences, and which is cultivated throughout the world. A number of viruses have been reported to occur naturally in $H$. macrophylla and other cultivated Hydrangea spp. These include $\mathrm{Al}$ falfa mosaic virus (AMV) $(6,12)$, Arabis mosaic virus (ArMV) (7), Cucumber mosaic virus (CMV) (22), Hydrangea mosaic virus (HdMV) (23), Hydrangea latent virus (HdLV) (3), Hydrangea ringspot virus (HdRSV) $(9,12,14)$, Impatiens necrotic spot virus (INSV) (19), Tobacco necrosis virus (TNV) (20), Tobacco rattle virus (TRV) (20), Tobacco ringspot virus (TobRSV) $(5,12)$, Tomato blackring virus (TBRV) (20), Tomato ringspot virus (TomRSV) (8), and Tomato spotted wilt virus (TSWV) (4). During 2005 and 2006, viruslike disease symptoms were observed on the popular variety Endless Summer in commercial retail outlets in Minnesota. Symptoms consisted of leaf blistering and reddening, rugosity, and chlorotic mottling. Filamentous viruslike particles 650 to $660 \mathrm{~nm}$ in length were observed by transmission electron microscopy (TEM)

Corresponding author: B. E. Lockhart

E-mail: lockh002@umn.edu

Accepted for publication 13 May 2009.

doi:10.1094/PDIS-93-9-0891

(C) 2009 The American Phytopathological Society in partially purified preparations from symptomatic leaf tissue, but not in similar preparations from asymptomatic plants. The study reported here was undertaken to determine the identity and properties of the filamentous virus associated with disease symptoms in Endless Summer, its role in the etiology of the disease, and its relationship to previously described viruses occurring in hydrangeas. This viruslike organism was tentatively named Hydrangea chlorotic mottle virus (HdCMV).

\section{MATERIALS AND METHODS}

Virus source, transmission, host range. The virus isolate used in this study was obtained from a single plant of the variety Endless Summer that showed viruslike symptoms of chlorotic mottling and leaf deformation and discoloration (Fig. 1A). Sources of the virus were maintained by vegetative propagation of infected material in which only carla-like virions and no HdRSV particles were detected in partially purified leaf extracts as described below. Also, the virus was transmitted by Myzus persicae, as described below, to virus-free plants of the same variety. Host range tests were done by mechanical inoculation of leaves of Carborundumdusted indicator plants using crude leaf extracts prepared in $100 \mathrm{mM}$ sodium phosphate buffer, $\mathrm{pH}$ 7.0, containing $0.25 \%$ (vol/vol) 2-mercaptoethanol. Indicator plants were kept in the greenhouse at 22 to $25^{\circ} \mathrm{C}$ for up to 10 months postinoculation. Inoculated plants were observed for symptoms and tested for the presence of
HdCMV by TEM using partially purified extracts, by immunosorbent electron microscopy (ISEM), and by enzyme-linked immunosorbent assay (ELISA) as described below. Aphid transmission tests were done using nonviruliferous apterae of $M$. persicae raised on Chinese cabbage. After a 1-h preacquisition fast, the aphids were allowed a 1- to 5-min acquisition access period on infected Endless Summer source plants and then transferred in lots of 10 to each of five healthy test plants of the same variety. After a 12-h inoculation access period, the aphids were killed by application of the insecticide Mavrik Aquaflow. Inoculated plants were kept in the greenhouse 10 months postinoculation and were observed for symptom expression and assayed for the presence of HdCMV.

Virion purification, electron microscopy, serology. Partially purified preparations of HdCMV for TEM and ISEM studies were obtained from 2- to 5-g leaf tissue samples as described previously (2).

For characterization studies and antiserum production, virions of HdCMV were extracted from infected leaf tissue as described above for preparation of partially purified extracts and further purified by isopycnic density gradient centrifugation in $30 \%$ (wt/wt) $\mathrm{Cs}_{2} \mathrm{SO}_{4}$ for $24 \mathrm{~h}$ at 180,000 $\times g_{\max }$ and $14^{\circ} \mathrm{C}$. Gradients were fractionated from the bottom using Fluorinert (Sigma). Fractions containing virions were identified by TEM examination following negative staining with $2 \%$ sodium phosphotungstate (PTA), $\mathrm{pH} 7.0$, containing $250 \mu \mathrm{g} / \mathrm{ml}$ bacitracin, 2\% ammonium molybdate (AM), $\mathrm{pH} 6.8$, or aqueous uranyl formate (UF). Microscope magnification was calibrated using the lattice spacing of potassium permanganatestained catalase crystals (24). Fractions containing detectable plant debris were discarded. Virion-containing fractions were pooled and diluted with 5 volumes of distilled water $\left(\mathrm{dH}_{2} \mathrm{O}\right)$. The virions were collected by ultracentrifugation at $184,000 \times g_{\max }$ for $2 \mathrm{~h}$, and the resulting pellets were resuspended in $\mathrm{dH}_{2} \mathrm{O}$. The purity of virion suspensions was assessed by the $A_{260} / A_{280}$ ratio and TEM examination. Virus concentration was estimated using an assumed extinction coefficient $\left(\mathrm{E}_{260}{ }^{0.1 \%}\right)$ of 3.0.

An antiserum against HdCMV antigen was prepared by immunizing a New Zea- 
land white rabbit with purified virus emulsified 1:1 in Titermax Gold adjuvant (Sigma). Injections were administered subcutaneously at days $0(1 \mathrm{mg}), 14$ (0.5 $\mathrm{mg})$, and $21(0.5 \mathrm{mg})$. Blood samples were taken at weekly intervals starting at day 56. The specific antibody titer of serum samples was determined by indirect ELISA (15) using crude sap from healthy and HdCMV-infected Endless Summer as coating antigen. Subsequent virus detection assays were done by indirect ELISA and by ISEM (17). Antiserum to HdRSV (ATCC PV-785) was obtained from the American Type Culture Collection and was used for detection of HdRSV by ISEM and indirect ELISA.

Cloning and sequence analysis. The sequence of a 1.7-kb fragment of the $3^{\prime}$ end of the HdCMV genome was obtained from amplicons generated by polymerase chain reaction (PCR) amplification following cDNA synthesis. First-strand cDNA synthesis was done using genomic RNA extracted from purified virions, the primer M4T (10) and the Universal Riboclone
cDNA synthesis system (Promega, Madison, WI) according to manufacturer's instructions. Amplification of the $3^{\prime}$ terminus of the HdCMV genome was done using first-strand cDNA as template and the primer pair pCar1 (11) and M4 (10,11). The resulting amplicon was cloned using a TOPO TA cloning kit (Invitrogen, Carlsbad, CA). Cloned inserts were identified by PCR using M13 forward and reverse primers. Plasmid DNA was extracted from an overnight culture of selected clones using a QIAprep Spin Minprep Kit (Qiagen) and sequenced at the University of Minnesota Bio-Medical Genomics Center. Nucleotide sequences were aligned and translated using Sequencher, version 4.2 (Gene Codes Corporation). Similarity searches of nonredundant sequences in the GenBank database were performed using BLAST (National Center for Biotechnology Information, Bethesda, MD, USA). The HdCMV sequence was aligned with the corresponding sequences of other species in the genus Carlavirus. Nucleic acid alignments were constructed using
CLUSTAL X (1.81) with default parameters (18). Alignments were refined using MacClade 4 version 4.6 (18). The coding capacity of the HdCMV partial sequence was screened looking for all reading frames using the open reading frame (ORF) Finder program (National Center for Biotechnology Information, Bethesda, MD, USA). The sequence has been deposited in GenBank (Acc. no. DQ412999). A phylogenetic tree to show the relationship between HdCMV and some representative members of the genus Carlavirus was constructed using Clustal W2 (16) for the initial alignment of the nucleotide sequences of the coat protein region. Discovery Studio Gene (DS gene) (1) version 1.5 was used to further align the sequences before constructing a neighbor-joining tree with 1,000 bootstrap replicates using Phylogenetic Analysis Using Parsimony (PAUP) (21). The following GenBank accession numbers were used in constructing this tree: Potato virus M (NC001361), Cole latent virus (AY340584), Aconitum latent virus (NC_002795), Hop latent virus
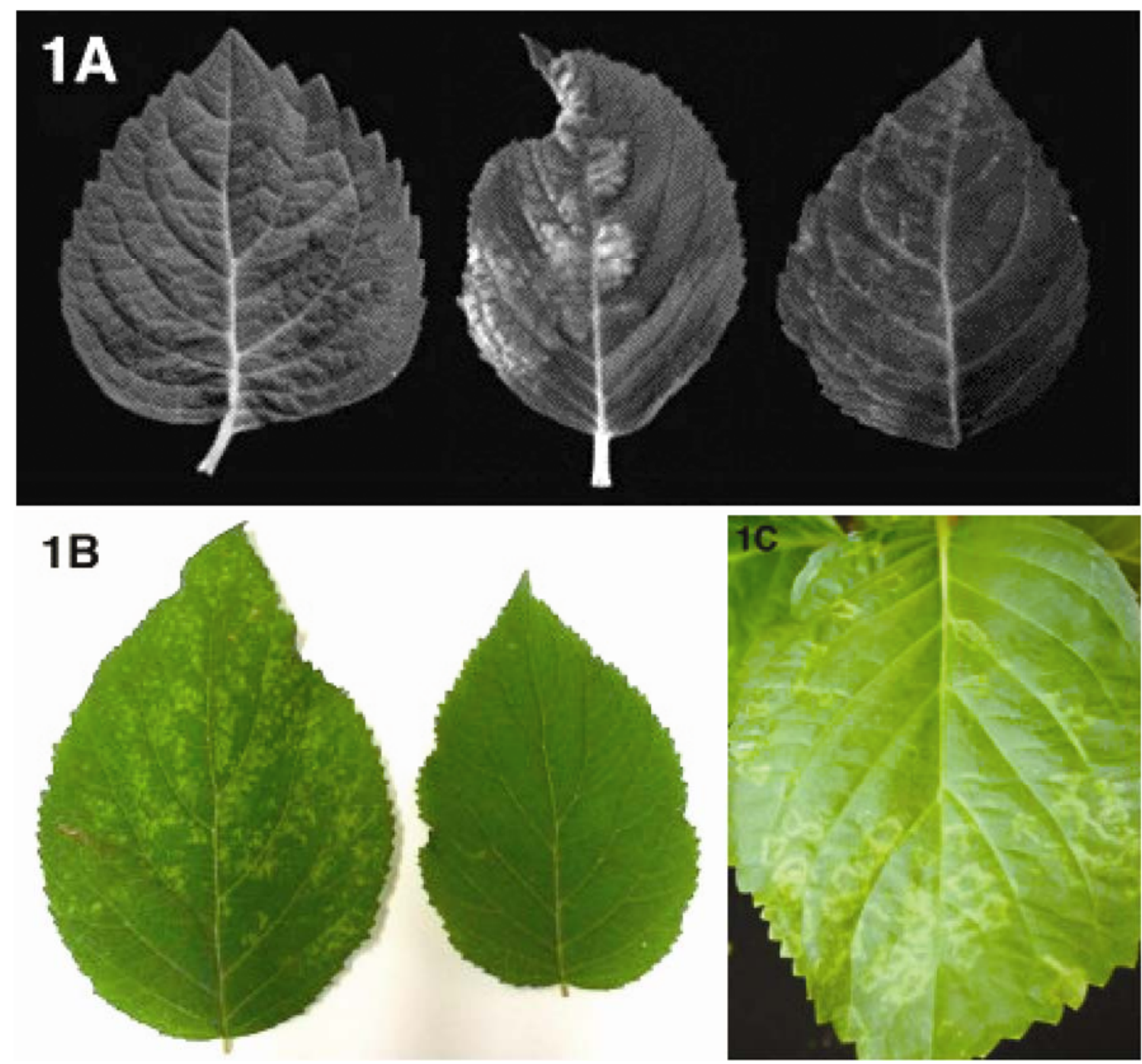

Fig. 1. Foliar symptoms in florists' hydrangea (Hydrangea macrophylla) infected naturally with Hydrangea chlorotic mottle virus (HdCMV). A, Leaf distortion and blistering (center) and chlorotic mottle (right) in H. macrophylla 'Endless Summer'. Healthy leaf is on the left. B, Chlorotic mottle in H. macrophylla 'Early Sensation' (left). Healthy leaf is on the right. C, Chlorotic ring spots in H. macrophylla 'Sister Therese'. 
(NC_002552), Cowpea mild mottle virus (AF024629), Chrysanthemum virus B (NC_009087), Helenium virus $S$ (D10454), Blueberry scorch virus (NC_003499), Kalanchoë latent virus (AY238143), Garlic latent virus (NC_003557), Alfalfa latent virus (AY037925), Poplar mosaic virus (NC_005343), Carnation latent virus (AJ010697), and Sweet potato chlorotic fleck virus (NC_006550). Potato virus $X$ (Z34261) and Hosta virus $X$ (FJ821705) were used as outgroup sequences.

\section{RESULTS}

Disease incidence and symptoms. Durin the following eight $H$. macrophylla varieties from Minnesota, Missouri, and New York: Endless Summer, Early Sensation, Blau Doneau (Minnesota), David Ramsey, Decatur Blue, Oakhill, Penny Mac (Missouri), and Sister Therese (New York). Ten to 15 plants of each of the first three varieties were obtained from retail outlets in Minneapolis and St. Paul. All tested positive for presence of HdCMV. Four plants each of David Ramsey, Decatur Blue, Oakhill, and Penny Mac were purchased from a supplier in Missouri and were all found to be infected by HdCMV. A single HdCMV-infected plant was obSymptoms in naturally infected plants consisted of leaf mottling, blistering, and reddening and both chlorotic and ring spots (Fig. 1). No other viruslike particles were detected by TEM or ISEM in partially purified preparations from the plants showing the symptoms illustrated in Figure 1A to C. Symptoms associated with HdCMV infection were investigated most closely in Endless Summer plants in Minnesota. The symptoms described above were observed most frequently early in the year (April-June) and were less evident during the summer (JuneSeptember). Similar data were not obtained for the other hydrangea cultivars listed above. ing 2005 to 2007, HdCMV was identified tained from a garden center in New York.

Virus transmission and host range, disease etiology. The results of virus transmission tests carried out by mechanical inoculation are presented in Table 1. These data show that HdCMV was transmitted readily from infected to healthy $H$. macrophylla, but not to any other indicator plants, including $H$. arborescens and $H$. paniculata or to three other genera in the family Saxifragaceae (Astilbe, Heuchera, and Ribes). Experimentally infected $H$. macrophylla plants developed symptoms similar to some observed in naturally infected hydrangeas (Fig. 1D), and the presence of HdCMV and absence of HdRSV in these test plants was confirmed by ISEM as described above. No symptoms were observed in any of the other indicator plants, some of which were kept for up to 10 months postinoculation. All indicator plants were tested by ISEM and ELISA and were negative for HdCMV. The green peach aphid, $M$. persicae, transmitted HdCMV to six of six healthy Endless Summer test plants following a short acquisition access period on infected Endless Summer source plants. These infected plants developed symptoms similar to some of those observed in the source plants, and the presence of HdCMV was confirmed, as before, by ISEM.

Virion purification, electron microscopy, serological tests. Virions of HdCMV purified by isopycnic density gradient centrifugation were shown by TEM examination to be free of contaminating host plant cell debris (Fig. 2A). Rabbit antibodies raised against purified HdCMV virions were effective in detecting HdCMV by ISEM and ELISA and in distinguishing clearly between HdCMV and HdRSV by ISEM (Fig. 2B and C) and ELISA (data not shown).

Cloning and sequence analysis. One partial and three complete putative open reading frames were identified in the $\sim 1$.7$\mathrm{kb} \mathrm{3}$ 'terminal region of the HdCMV genome (Fig. 3). As indicated in Table 2, the highest amino acid identity between the

Table 1. Experimental host range of Hydrangea chlorotic mottle virus (HdCMV) determined by mechanical inoculation of indicator plants with sap extracts

\begin{tabular}{llc}
\hline Indicator plant & Family & $\begin{array}{c}\text { No. of plants infected/ } \\
\text { No. of plants inoculated }\end{array}$ \\
\hline Hydrangea macrophylla 'Nikko Blue' & Saxifragaceae & $2 / 2$ \\
H. macrophylla 'Endless Summer' & Saxifragaceae & $9 / 9$ \\
H. arborescens & Saxifragaceae & $0 / 1$ \\
H. paniculata & Saxifragaceae & $0 / 2$ \\
Astilbe arendsii & Saxifragaceae & $0 / 3$ \\
Heuchera sp. & Saxifragaceae & $0 / 3$ \\
Ribes sp. & Saxifragaceae & $0 / 4$ \\
Nicotiana benthamiana & Solanaceae & $0 / 5$ \\
N. occidentalis & Solanaceae & $0 / 5$ \\
N. clevelandii & Solanaceae & $0 / 5$ \\
Chenopodium quinoa & Chenopodiaceae & $0 / 5$ \\
Pisum sativum & Fabaceae & $0 / 5$ \\
Phaseolus vulgaris & Fabaceae & $0 / 5$ \\
Cucumis sativus & Cucurbitaceae & $0 / 5$ \\
Spinacia oleracea & Amaranthaceae & $0 / 5$ \\
Gomphrena globosa & Amaranthaceae & $0 / 5$ \\
\hline
\end{tabular}

putative proteins encoded by this 1.7-kb $3^{\prime}$ terminus of the HdCMV genome was to known members of the genus Carlavirus as determined by BLAST algorithm. These data indicate clearly that HdCMV is a member of the genus Carlavirus but differs significantly from previously characterized carlaviruses. The amino acid sequence of the HdCMV coat protein (CP) shares $65 \%$ sequence homology with the corresponding region of KLV. This is less than $68 \% \mathrm{CP}$ sequence homology required for species demarcation in the genus Car-

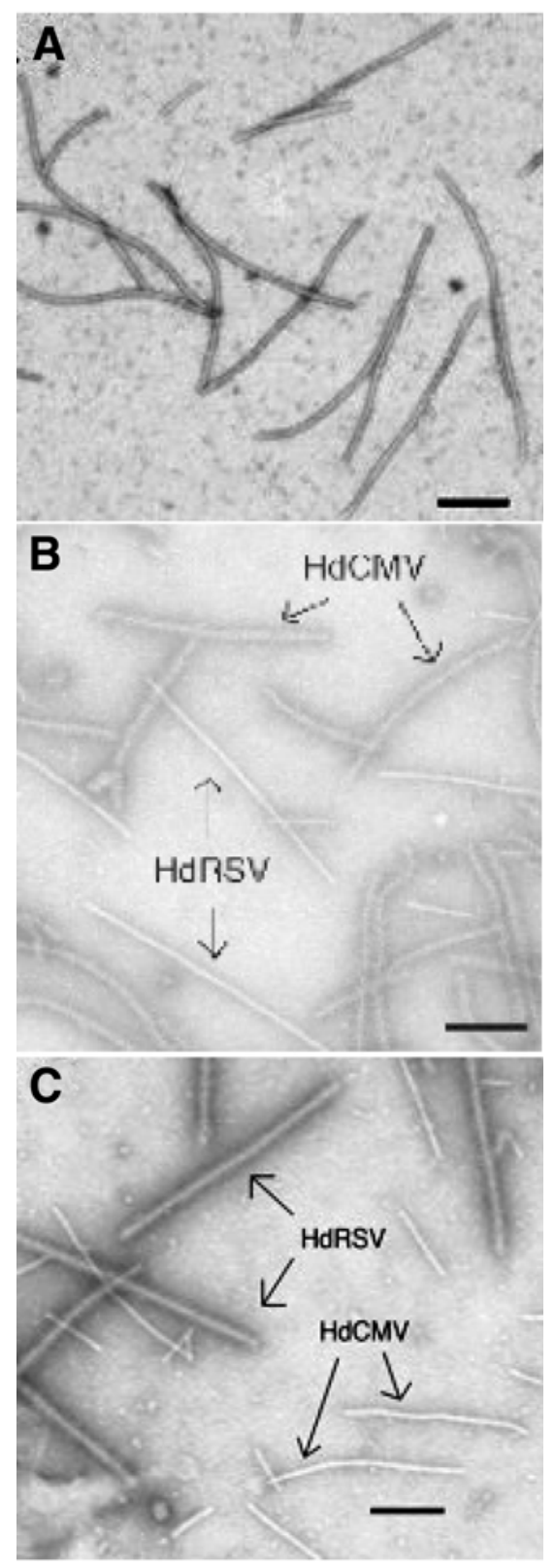

Fig. 2. Virions of Hydrangea chlorotic mottle virus (HdCMV) and specific detection of HdCMV and Hydrangea ringspot virus by immunosorbent electron microscopy (ISEM) using homologous antisera. A, Purified preparation of HdCMV virions negatively stained with aqueous uranyl formate. Immuno-specific detection of HdCMV (B) and HdRSV (C) using homologous antisera. Virions are negatively stained with $2 \%$ sodium phosphotungstate, $\mathrm{pH}$ 7.0. Scale bar represents $200 \mathrm{~nm}$. 
lavirus (13). The partial ORF (80 amino acids) corresponds to the carlavirus ORF 3. An ORF encoding a $7.6-\mathrm{kDa}$ protein corresponds to the carlavirus ORF 4 and is followed by an intergenic region of 27 nucleotides. These two ORFs correspond to the second and third ORFs in the carlavirus triple gene block (TGB). A 32$\mathrm{kDa}$ protein is encoded by a gene analogous to carlavirus ORF 5 that encodes the viral CP. This is followed by an intergenic region of 21 nucleotides. The $3^{\prime}$ terminal ORF (12 kDa) corresponds to the carlavirus ORF 6, which codes for a nucleic acid binding protein (13). The relationship of HdCMV to some representative members of the genus Carlavirus is illustrated in Figure 4.

\section{DISCUSSION}

Based on the data presented above, including Table 2 and Figures 3 and 4, it was concluded that HdCMV meets the criteria for inclusion as a new Carlavirus species that is aphid-transmitted with an experimental host range limited to $H$. macrophylla, in which it induces a variety of symptoms. In some instances, HdCMV occurs in mixed infection with HdRSV, but it is clear that HdCMV infection induces symptoms in $H$. macrophylla independent of coinfection with HdRSV. Serological tests can reliably detect and differentiate between HdCMV and HdRSV, and can be used to identify and eliminate plants that can be sources of infection. Limited sampling identified HdCMV in Minnesota, Missouri, and New York. This suggests that HdCMV may occur widely in $H$. macrophylla and warrants a wider investigation of its occurrence, distribution, and correlation with abnormal appearance or growth patterns in hydrangeas. The occurrence of HdCMV has been recently confirmed in New Zealand. The reported sequence (EU754720) had 97\% nucleotide sequence identity to the corresponding region of the HdCMV genome (DQ412999), indicating that the viruses are very closely related. This is especially important because HdCMV, unlike HdRSV, is readily aphid transmitted and therefore has the potential for rapid spread in field-cultivated hydrangeas. Contrary to earlier expectations, the highly popular

Table 2. Highest amino acid sequence identities between Hydrangea chlorotic mottle virus (HdCMV) ORFs comprising the 1.7-kb $3^{\prime}$ terminus of the viral genome and known members of the genus Carlavirus

\begin{tabular}{|c|c|c|c|}
\hline $\begin{array}{l}\text { Carlavirus } \\
\text { ORF }\end{array}$ & $\begin{array}{c}\text { Size } \\
\text { (amino acids) }\end{array}$ & Species with highest sequence identity & Identities \\
\hline ORF $3^{\text {(partial) }}$ & 80 & $\begin{array}{l}\text { Blueberry scorch virus } 12 \mathrm{kDa} \text { Triple gene } \\
\text { block protein } 2 \text { (NC_003499) }\end{array}$ & $55 / 106(52 \%)$ \\
\hline ORF 4 & 69 & $\begin{array}{l}\text { Blueberry scorch virus } 7 \mathrm{kDa} \text { Triple gene } \\
\text { block protein } 3 \text { (NC_003499) }\end{array}$ & $31 / 64(48 \%)$ \\
\hline ORF 5 & 288 & $\begin{array}{l}\text { Kalanchö̈ latent virus capsid protein } \\
(\mathrm{AY} 238143)^{\mathrm{a}}\end{array}$ & $186 / 284(65 \%)$ \\
\hline ORF 6 & 111 & $\begin{array}{l}\text { Blueberry scorch virus nucleic acid-binding } \\
\text { protein (NC_003499) }\end{array}$ & $72 / 110(65 \%)$ \\
\hline
\end{tabular}

a GenBank accession numbers.

\section{Carlavirus}

ORF1
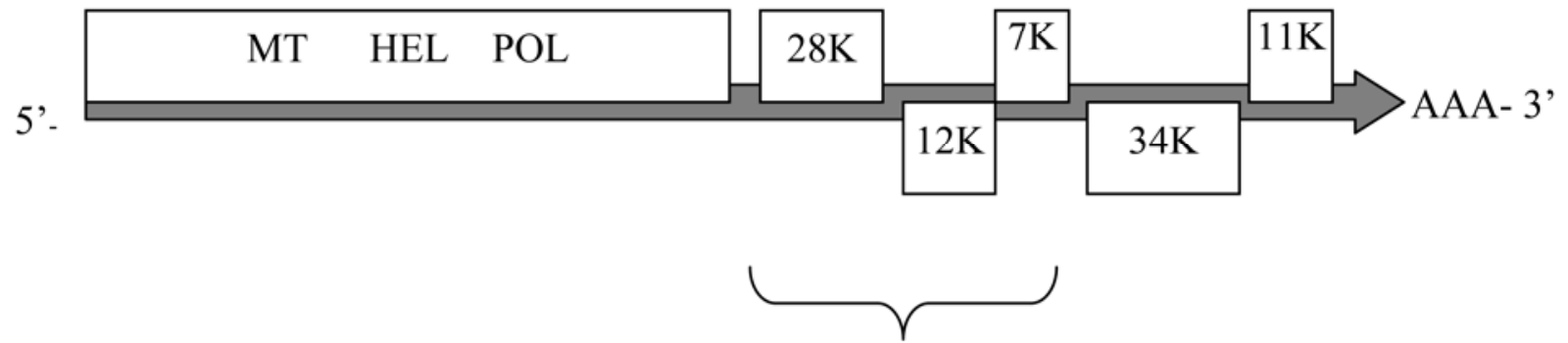

TRIPLE GENE BLOCK

\section{HdCMV}

ORF3 ORF4 ORF5 ORF6

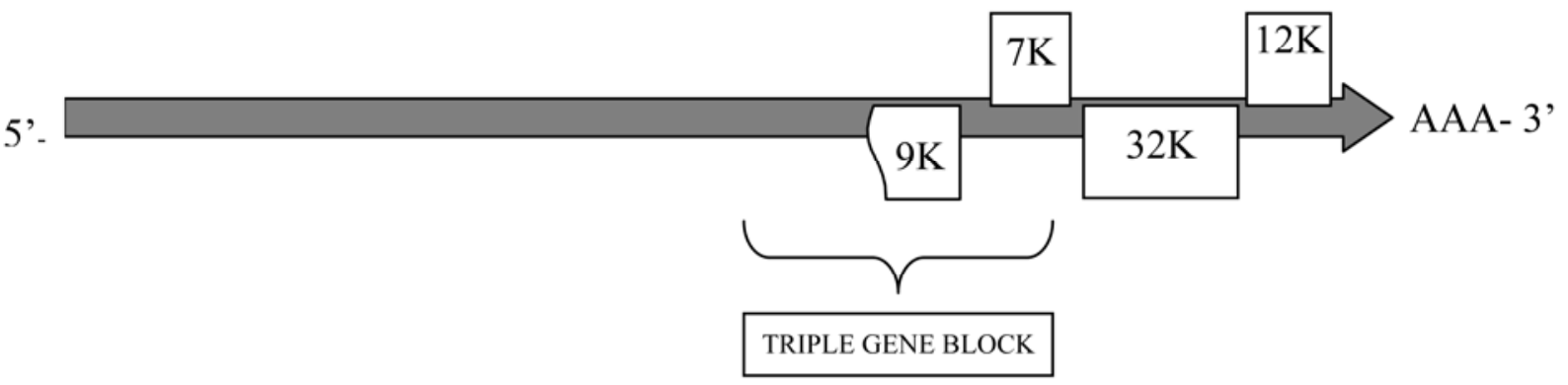

Fig. 3. Schematic representation of the arrangement of putative open reading frames (ORFs) identified in the 1.7-kb $3^{\prime}$ terminus of the Hydrangea chlorotic mottle virus (HdCMV) genome compared to the genome organization of members of the genus Carlavirus $(\mathrm{MT}=$ methyltransferase; $\mathrm{HEL}=$ helicase; $\mathrm{POL}=$ polymerase). 
cultivar Endless Summer has been found to be frequently susceptible to winter damage in Minnesota. It would be of interest to determine whether a correlation exists between winter hardiness and infection by HdCMV in this and possibly other hydrangea cultivars.

The carlavirus Hydrangea latent virus (HdLV) (3) was reported to occur in six $H$. macrophylla varieties, including Sister Therese, in which HdCMV was identified in this study. It is possible that HdCMV and HdLV are the same virus, although this cannot be proven. The latter was assumed to be a carlavirus solely on the basis of the particle length and morphology, and it was also assumed that the viruslike particles observed by TEM in all five varieties (Sister Therese, Stafford, Botstein, Kasteln, and Matible Gulges) were particles of the same virus, but this was not confirmed. It was also reported that HdLV was not transmitted by mechanical inoculation to H. macrophylla (3). This contrasts with HdCMV, which was transmitted readily to $H$. macrophylla by both mechanical inoculation and $M$. persicae. Another interesting difference between HdCMV and HdLV is that whereas the latter virus was described as occurring in very low concentrations, the concentration of HdCMV virions in infected plants was found to be uniformly high throughout this study. Due to the paucity of information on HdLV associated with ringspot symptoms, it is not possible to establish any definitive relationship between these two viruses. However, it is possible that they may be the same or closely related. It is therefore possible that HdCMV may have been previously present but not detected in hydrangeas in the United States, and that disease symptoms attributed to infection by HdRSV may have in some cases been due, in fact, to infection by HdCMV.

\section{LITERATURE CITED}

1. Accelrys Inc. 2003. Discovery Studio Gene (DSgene) version 1.5 software program. Accelrys Inc., San Diego, CA.

2. Ahlawat, Y. S., Pant, R. P., Lockhart, B. E. L., Srivastava, M., Chakraborty, N. K., and Varma, A. 1996. Association of a badnavirus with citrus mosaic disease in India. Plant Dis. 80:590592.

3. Allen T. C., McMorran, J. P., and Lawson, R. H. 1985. Detection and identification of viruses in hydrangeas. Acta Hortic. 164:85-89.

4. Allen, T. C., McMorran, J. P., and Locatelli, E. A. 1983. Isolation of tomato spotted wilt virus

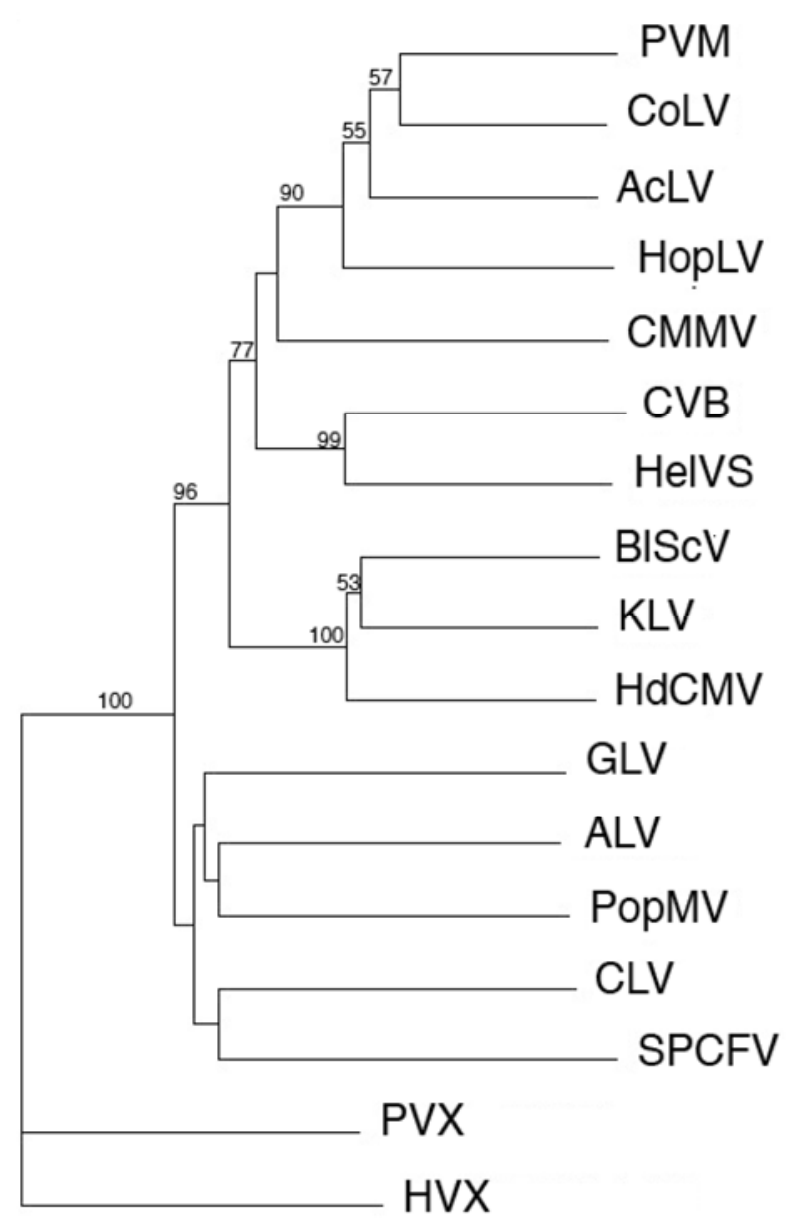

Fig. 4. Relationship of Hydrangea chlorotic mottle virus (HdCMV) to known species in the genus Carlavirus based on a phylogenetic tree generated by the nucleotide sequences of the respective coat protein. Numbers at each branch indicate percentage of bootstrap analysis that supports the grouping at that node (for 1,000 replicates). Bootstrap values are shown as percent value, and only nodes with values over $50 \%$ are labeled. from hydrangea and four weed species. Plant Dis. 67:429-431.

5. Anderson, C. W. 1958. Tobacco ringspot of florists' hydrangea. Plant Dis. Rep. 42:932934.

6. Belli, G. 1968. Ricerche su una clorosi nevale dell ortensia. Phytopathol. Mediterr. 7:70-71.

7. Belli, G., and Belli, G. G. 1969. Isolamento di un ceppo di virus del mosaico dell' Erba Medica da piante di Ortensia. Ann. Phytopathol. (H.S.) 1:341-345.

8. Brierly, P. 1954. Symptoms in the florists' hydrangea caused by tomato ringpot virus and an unidentified sap-transmissible virus. Phytopathology 44:696-699.

9. Brierly, P., and Lorentz, P. 1957. Hydrangea ringspot virus, the probable cause of 'running out' of the florist's hydrangea. Phytopathology 47:39-43.

10. Chen, J., Chen, J., and Adams, M. J. 2001. A universal PCR primer to detect members of the Potyvridae and its use to examine the taxonomic status of several members of the family. Arch. Virol. 146:757-761.

11. Chen, J., Chen, J., and Adams, M. J. 2002. Characterization of some carla- and poty viruses from bulb crops in China. Arch. Virol. 147:419-428.

12. Chiko, A. W., and Godkin, S. E. 1986. Occurrence of alfalfa mosaic, hydrangea ringspot, and tobacco ringspot viruses in Hydrangea spp. in British Columbia. Plant Dis. 70:541 544.

13. Fauquet, C. M., Mayo, M. A., Maniloff, J., Desselberger, U., and Ball, L. A., eds. 2005. Virus Taxonomy, VIIIth Report of the International Committee on Taxonomy of Viruses. Elsevier/Academic Press, London.

14. Koenig, R. 1973. Hydrangea ringspot virus. Descriptions of Plant Viruses No. 114 $\mathrm{CAB} / \mathrm{AAB}$, Commonw. Mycol. Inst., Kew, England.

15. Koenig, R., and Paul, H. L. 1982. Variants of ELISA in plant virus diagnosis. J. Virol. Methods 5:113-125.

16. Larkin, M. A., Blackshields, G., Brown, N. P., Chenna, R., McGettigan, P. A., McWilliam, H., Valentin, F., Wallace, I. M., Wilm, A., Lopez, R., Thompson, J. D., Gibson, T. J., and Higgins, D. G. 2007. Clustal W and Clustal X version 2.0. Bioinformatics 23:2947-2948.

17. Lockhart, B. E. L., Autrey, L. J. C., and Comstock, J. C. 1992. Partial purification and serology of sugarcane mild mosaic virus, a mealybug-transmitted closterolike virus. Phytopathology 82:691-695.

18. Maddison, W. P., and Maddison, D. R. 2000 MacClade: Analysis of phylogeny and character evolution, v. 4. Sinauer, Sunderland, MA

19. Ruter, J. M., and Gitaitis, R. D. 1993. Impatiens necrotic spot virus in woody landscape plants in Georgia. Plant Dis. 77:318.

20. Schmelzer, K. 1970. Untersuchungen an Viren der Zier- und Wildgeholze.7. Mitteilung: Meitere Befunde an Buddleja, Viburnum, Caryopteris und Philadelphus sowie viren an Leycesteria, Chionanthus, Ribes, Hydrangea Syringa, Spiraea und Catalpa. Phytopathol. Z 67:285-326.

21. Swofford, D. L. 1998. Phylogenetic Analysis Using Parsimony (*and Other Methods). Sinauer Associates, Sunderland, MA.

22. Tamura, M., and Kumoro, Y. 1967. The mosaic disease of Hydrangea caused by cucumber mosaic virus. Ann. Phytopathol. Soc. Jpn 33:27-31

23. Thomas, B. J., Barton, R. J., and Tuszynki, A. 1983. Hydrangea mosaic virus, a new ilarvirus from Hydrangea macrophylla (Saxifragaceae). Ann. Appl. Biol. 103:261-276.

24. Wrigley, N. G. 1968. The lattice spacing of crystalline catalase as an internal standard of length in electron microscopy. J. Ultrastruct. Res. 24:454-464. 